\title{
Aetiological agent in community acquired pneumonia in patients requiring hospitalization
}

$$
\text { المسببات الجرثومية لذات الرئة المكتسبة من المجتمع للمرضى الداخلين للمسنشفى }
$$

\section{Tural Yelderim Baker* Mushrik K. Abood Abdullah Mustafa Qader \\ *College of Health and Medical Biotechnology \\ Biotechnology Research Center/ Al-Nahrain University}

\begin{abstract}
This study was carried out to determine the etiological agents in patients with community-acquired pneumonia (CAP). Ninety-three patients with radiologically confirmed pneumonia admitted to the Medical City, Baghdad Teaching Hospital through the period extended from October 2001 till March 2002. Also to investigate a possible correlation between etiological agents in patients with CAP and comorbid factors including age. The etiological agents were identified from $50(53.8 \%)$ patients with CAP, while no agents were detected in 43 (46.2\%) patients. Blood samples were taken from all patients for identification of Chlamydia pneumoniae and Mycoplasma pneumoniae infection. Sputum samples for culture were taken from $76(81.7 \%)$ patients; bacterial species were isolated from 22 (23.7\%) samples. Streptococcus pneumoniae was the most frequent typical bacterial pathogen isolated from $17(18.3 \%)$ patients. Atypical pathogens (C. pneumoniae and $M$. pneumoniae) using ELISA technique were identified in $22(23.6 \%)$ and 20 (21.5\%) respectively. Atypical pathogens were a most common causes of CAP identified from $(39.8 \%)$ cases. Sixteen $(\mathbf{1 7 . 2 \% )}$ of the patients had mixed infections (two pathogens were identified in $12(75 \%)$ and three pathogens in $4(25 \%)$ patients). C. pneumoniae and $S$. pneumoniae were the most common mixed organisms found in $6(37.5 \%)$ of patients.

\footnotetext{
المستخلص

اجريت هذه الدراسة لتحديد المسبيات المرضية لدى المرضى المصابين بذات الرئة المكتسبة من المجتمع. كما تم البحث عن و جود علاقة بين المسببات المرضية و العوامل المهيئة للإصابة مثل العمر ـ تم تحديد المسببات المرضية في 50 (53.8\%) من المرضى و بذلك يكون عدد المرضى الذين لم تحدد المسبيات المرضية لهم 43 (46.2\%). وقد اخذت

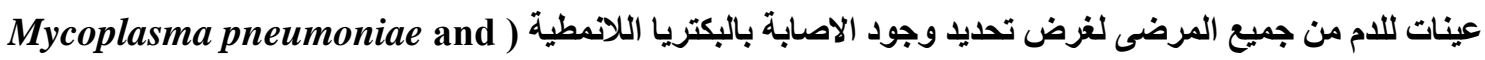
(Chlamydia pneumoniae ) . (ما عينات القشع فقد جمعت من 76 (81.7\%) مريض اعطت 22 (23.7\%) عينة منها نتائج موجبة بالزرع المختبري حيث كاتت المكورات الرئوية (Streptococcus pneumoniae) اكثر انواع
} 
البكتريا النمطية شيوعا فقد عزلت من 17 (18.3\%) مريض ـ و قد اثبتت هذه الدراسة ان البكتريا اللانمطية و التي تم تحديدها بواسطة طريقة الروز (Mycoplasma pneumoniae and Chlamydia pneumoniae) المناعي المرتبط بالانظيم (ELISA) هي من اكثر المسبيات شيوعا لذات الرئة المكتسب من المجتمع حيث شكلت مجتمعة (39.8\%) من مجموع المرضى. تم قياس الاجسام المضادة من نوع (IgM) و التي تؤكد الاصابة الحادة بالـ(Mycoplasma pneumoniae) في 22 (23.6) و بذلك تكون اكثر الجراثيم المحددة شيوعا تتبعها الـ(Chlamydia pneumoniae) و التي وجدت في 20 (21.5\%) مريض ـ و قـ اظهرت الدراسة ان 16 (17.2\%) من المرضى لديهم اصابة مشتركة فقد حدد مسببين مرضيين في 12 (75\%) من حالات الاصابات المشتركة و ثلاثة مسبيات في اربعة (25\%) من المرضى و شكلت اكثر خالات الاصابة المشتركة بين Chlamydia pneumoniae و Mycoplasma pneumoniae

\section{Introduction}

Despite advances in the management of severe infectious diseases, communityacquired pneumonia (CAP) remains the major cause of mortality and the six most common cause of death overall $[1,2]$. The disease is a common cause of hospital admission and presents challenge to physicians because a causative microorganism can be only found in about $50 \%$ of cases [3]. Despite more than a century of microbiological investigations, there is still uncertainty about the relative importance of the various organisms that cause pneumonia [4]. The urgent challenge in the management of CAP is the selection of appropriate antibiotic therapy. However, CAP can be caused by a myriad of pathogens with differing antimicrobial susceptibilities, and no sufficiently rapid

\section{Materials and Methods}

This study included 93 patients with CAP. They were 54 males (58\%) and 39 females $(42 \%)$. The age range was $15-86$ years and accurate battery of diagnostic tests for the cause of CAP is available presently. Furthermore, it has proved to be difficult to predict the etiology of CAP on the bases of presenting clinical and radiographic features [5,6]. Thus, initial antibiotic selection usually must be empirical and is based on the results of numerous studies of CAP etiology conducted [7]. The understanding of the pathogens most frequently involved is a key consideration in the choice of empirical antibiotic therapy [1]. A prospective study was conducted in order to determine the etiological agents of community-acquired bacterial pneumonia in adult population requiring hospitalization to guide the empirical antibiotic therapy.

with mean 45 years. Patients were admitted to the Medical City, Baghdad Teaching Hospital between October 2001 
and March 2002. Diagnosis of pneumonia was made depending on clinical and radiological findings. Blood samples were collected from all patients, while sputum samples were collected from $76(81 \%)$ of them. $60(79 \%)$ sputum samples were suitable for culture (considering $>25$ neutrophils and $<10$ epithelial cells as a valid specimen, evaluated by gram-stain

\section{Results}

Out of 93 patients studied, the etiological agents were identified in $50(53.8 \%)$ patients either by isolation of the causative organisms on culture media or by detection of the host's specific immune response by serology. While no etiologic agents were detected in 43 (46.2\%) patients of the total population studied.

Typical bacterial species causes of pneumonia were isolated from $22(23.7 \%)$ of patients figure (1). The most frequently and culture). A total of 50 patients with age $\geq 15$ years, attend to hospital complaining diseases other than pneumonia, were examined as a control group. ELISA technique (PLATELIA, Sanofi, Japan) was used for evaluation presence a specific IgM-anti Chlamydia pneumoniae and IgM-anti Mycoplasma pneumoniae antibodies in serum samples.

isolated organism was $S$. pneumoniae which was isolated from 17 (18.3\%) patients table (1). Atypical pathogens ( $M$. pneumoniae and $C$. pneumoniae) were identified in 37 (39.8\%) out of patients (all diagnosed serologically by detection of specific IgM antibodies) as shown in figure (1). Table (1) revealed that $M$. pneumoniae identified in 22 (23.6\%), while $C$. pneumoniae was identified in $20(21.5 \%)$.

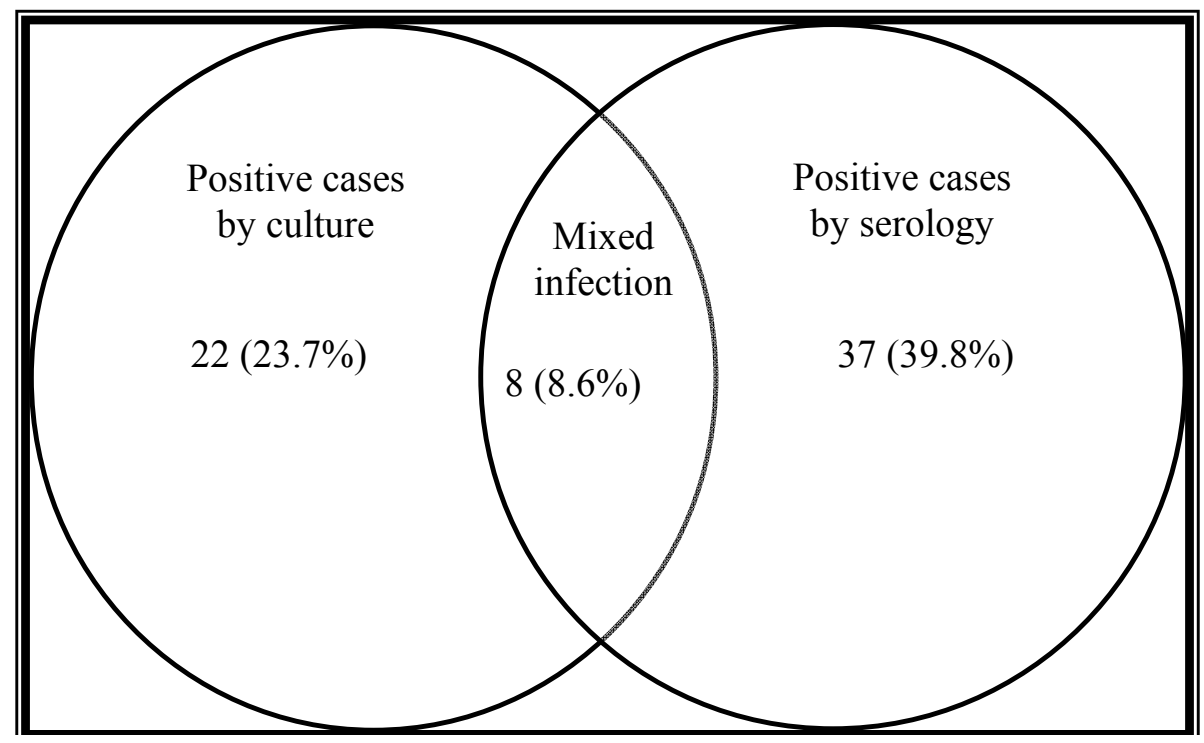

Figure (1): Major etiologic groups of 93 patients with community-acquired pneumonia requiring hospitalization. 
Table (1): Numbers and percentages of pathogens detected in 93 adult patients with community-acquired pneumonia requiring hospitalization.

\begin{tabular}{|c|c|c|}
\hline Pathogens & Number & $\%$ \\
\hline Bacterial pathogens & 28 & 30.1 \\
\hline S. pneumoniae & 17 & 18.3 \\
\hline H. influenzae & 2 & 2.15 \\
\hline S. aureus & 1 & 1.07 \\
\hline S. pyogens & 1 & 1.07 \\
\hline M. catarrhalis & 1 & 1.07 \\
\hline Aerobic GNB* & 6 & 6.5 \\
\hline K. pneumoniae & 2 & 2.15 \\
\hline E. coli & 2 & 2.15 \\
\hline P. aeruginosa & 2 & 2.15 \\
\hline Atypical pathogens & 42 & 45.16 \\
\hline M. pneumoniae & 22 & 23.6 \\
\hline C. pneumoniae & 20 & 75.3 \\
\hline Total & 70 & 21.5 \\
\hline
\end{tabular}

In this study only a single identified pathogen was verified in 34 (36.6\%) patients, and 16 (17.2\%) patients had two or more etiologic agents (mixed infections) table (2). This table also shows that 11 (55\%) of 20 C. pneumoniae infections were mixed and the most frequent identified pathogen mixed to others.

This study shows that the majority of bacterial pathogens causing pneumonia were identified more frequently (24.7\%) among patients at age 15-24 years, while at least frequent pathogens identified (3.2\%) at age 35-44 years. $(\mathrm{p}<0.001)$.

Table (3) shows the association between specific microorganisms and specific age group. For the first interval of age (15-24 years) only $M$. pneumoniae plays a highly significant role $(\mathrm{p}<0.001)$. For a second interval 25-34 years, only C. pneumoniae plays highly significant role $(\mathrm{p}<0.001)$. 
Table (2): Numbers and percentages of pathogens in 50 patients with identified cause of community-acquired pneumonia requiring hospitalization.

\begin{tabular}{|c|c|c|c|}
\hline Organism & $\begin{array}{l}\text { Single infection } \\
\text { No (\%)* }\end{array}$ & $\begin{array}{c}\text { Mixed infection with } \\
\text { other organism No (\%)* }\end{array}$ & $\begin{array}{c}\text { Total } \\
\text { No (\%) }\end{array}$ \\
\hline $\begin{array}{c}\text { Typical bacterial } \\
\text { pathogens }\end{array}$ & $10(35.7)$ & 18 (64.3) & 28 \\
\hline S. pneumoniae & $7(41.2)$ & $10(58.8)$ & 17 \\
\hline H. influenzae & - & $2(100)$ & 2 \\
\hline S. aureus & - & $1(100)$ & 1 \\
\hline S. pyogens & $1(100)$ & - & 1 \\
\hline M. catarrhalis & $1(100)$ & - & 1 \\
\hline K. pneumoniae & - & $2(100)$ & 2 \\
\hline E. coli & - & $2(100)$ & 2 \\
\hline P. aeruginosa & $1(50)$ & $1(50)$ & 2 \\
\hline Atypical pathogens & $24(70.6)$ & $18(50)$ & 42 \\
\hline M. pneumoniae & $15(68.2)$ & 7 (31.8) & 22 \\
\hline C. pneumoniae & $9(45)$ & $11(55)$ & 20 \\
\hline Total & $34(48.6)$ & $36(51.4)$ & 70 \\
\hline
\end{tabular}

* (\%) is calculated to the total number of pathogen identified.

Table (3): Impact of age on microbial etiology of community-acquired pneumonia requiring hospitalization.

\begin{tabular}{|c|c|c|c|c|c|}
\hline $\begin{array}{l}\text { Age } \\
\text { group }\end{array}$ & $\begin{array}{l}\text { Number of } \\
\text { patients }\end{array}$ & Microbial etiology & $\begin{array}{l}\text { Proportion of patients with } \\
\text { corresponding etiology }\end{array}$ & $\begin{array}{l}\text { Odds } \\
\text { ratio }\end{array}$ & p value \\
\hline $15-24$ & 21 & $\begin{array}{l}\text { S. pneumoniae } \\
\text { C. pneumoniae } \\
\text { M. pneumoniae }\end{array}$ & $\begin{array}{c}3 / 17(17.6 \%) \\
2 / 20(10 \%) \\
16 / 22(72.7 \%)\end{array}$ & $\begin{array}{c}0.7 \\
0.31 \\
35.2\end{array}$ & $\begin{array}{c}0.590 \\
0.230 \\
<0.001\end{array}$ \\
\hline $25-34$ & 16 & $\begin{array}{l}\text { S. pneumoniae } \\
\text { C. pneumoniae } \\
\text { M. pneumoniae }\end{array}$ & $\begin{array}{c}3 / 17(17.6 \%) \\
9 / 20(45 \%) \\
4 / 22(18.2 \%)\end{array}$ & $\begin{array}{c}1.03 \\
7.7 \\
1.09\end{array}$ & $\begin{array}{c}\mathbf{0 . 9 5 7} \\
<\mathbf{0 . 0 0 1} \\
\mathbf{0 . 8 8 9}\end{array}$ \\
\hline $35-44$ & 8 & $\begin{array}{l}\text { S. pneumoniae } \\
\text { C. pneumoniae }\end{array}$ & $\begin{array}{l}1 / 17(5.9 \%) \\
1 / 20(5 \%)\end{array}$ & $\begin{array}{c}0.6 \\
0.49\end{array}$ & $\begin{array}{l}0.658 \\
0.517\end{array}$ \\
\hline
\end{tabular}




\begin{tabular}{|c||c|c||c||c|c|}
\hline $45-54$ & 13 & S. pneumoniae & $2 / 17(11.8 \%)$ & 0.78 & 0.771 \\
& & C. pneumoniae & $3 / 20(15 \%)$ & 1.11 & 0.882 \\
\hline \hline $55-64$ & 16 & S. pneumoniae & $3 / 17(17.6 \%)$ & 1.03 & 0.957 \\
& & C. pneumoniae & $3 / 20(15 \%)$ & 0.81 & 0.768 \\
\hline \hline$\geq 65$ & \multirow{2}{*}{19} & S. pneumoniae & $5 / 17(29.4 \%)$ & 1.84 & 0.310 \\
& & C. pneumoniae & $2 / 20(10 \%)$ & 0.36 & 0.192 \\
& & M. pneumoniae & $2 / 22(9 \%)$ & 0.31 & 0.131 \\
\hline
\end{tabular}

\section{Discussion}

The major goal of this study was to establish the microbiological identification of CAP in hospitalized patients. The percentage of patients with positive identified agents was (53.8\%), while those with unidentified microbial agents were (46.2\%). In the literature, the pathogens responsible for CAP were discovered in < 50 to $70 \%$ of patients $[8,9,10,11]$ depending on the types of diagnostic tests. The differences in the results is likely to be a reflection of a number of factors, including using different laboratory tests and various invasive procedures, or difficulty to make a precise diagnosis of the microbial agents causing pneumonia. There were a number of reasons that made difficulty in the identification of microbial agents in this study. First, 53.8\% of patients had received antimicrobial treatment before hospitalization, and this obviously lowered the identification yield. Second, the presence of unusual pathogens that go unrecognized (Legionella, Coxiella burnettii and fungi), the presence of viral infection or anon infection mimic of CAP. Finally, there may have been the presence of pathogens that are currently not identified or recognized.

In the current study, $S$. pneumoniae was the most frequently isolated bacteria identified as the cause of pneumonia in (18.3 \%) patients. In most studies $S$. pneumoniae was the most frequent etiology in adult patients with CAP $[12,13,14]$. Present study come in contrary with this finding In fact $S$. pneumoniae was identified as the third most frequent pathogen after $M$. pneumoniae and $C$. pneumoniae. Some studies $[9,15]$, reported that there was a change attributable to the increase in the number of patients who are older or who have underlying disease, the development of more sensitive diagnostic technique, and the consideration of $C$. pneumoniae as a respiratory pathogen.

Atypical microbial pathogens (C. pneumoniae and $M$. pneumoniae) were identified in (39. 8\%) patients with CAP in this study. In contrast to this result higher percentage was reported by different studies $[1,6,16,17,18]$ might be due to the presence or absence of epidemics of atypical microbial infections. Both $C$. 
pneumoniae and $M$. pneumoniae infections

occurs in cycles of several years [19, 20].

Another explanation might be due to the use of different serologic techniques and interpretative criteria.

The present study revealed that cases with mixed infections were identified in (17.2\%) of patients. The present study disagrees with [14, 17,21]. The difference may be attributed to a high number of the patients who had received prior antibiotics therapy. EL-Solh et al., [18] reported that the cases with mixed infections were more

\section{References}

1- Falguera M, Sacristán O, and Nogues A (2001). Nonsever Community-acquired pneumonia. Correlation Between Cause and Severity or Comorbidity. Arch Inter Med; 161: 1866-72.

2- Paganin F, Lilienthal F, Bourdin A, Lugagne N, Tixier F, Ge' nin R, Yvin JL (2004). Severe community-acquired pneumonia: assessment of microbial aetiology as mortality factor. Eur Respir J 2004; 24: 779-785.

3- González AR, Falguera M, Nogues A, and Rubio-Caballero M. (1999). Is Streptococcus pneumoniae the Leading Cause of Pneumonia of Unknown Etiology? A Microbiological Study of Lung Aspirate in Consecutive Patients with Community-acquired Pneumonia. The American J of Medicine; 106: 358390. likely to be identified in those who had not received preadmission antimicrobial treatment.

It is clear from this study that mixed infections most frequently found between typical and atypical pathogens. Atypical pathogens may predispose patient to a second infection is easily seen by their pathological effect on ciliated epithelium. Both infectious pathogens cause cilia stasis which makes the host more susceptible to infection by other more virulent pathogen such as S. pneumoniae [22,23].

4- Jokinen C, Heiskinen L, Junonen $H$, Kallinen S, Kleemola M, Koskela M, Leinonen $M$, Saikku $P$, Stén $M$, Tarkiainen A, Tukiainen H, Pyörälä K, and Mäkelä. (2001). Microbial Etiology of Community-acquired Pneumonia in the Adult Population of 4 Municipalities in Eastern Finland. Clin Infect Dis; 32: 1141-54.

5- Niederman MS (1994). Empirical therapy of community-acquired pneumonia. Semin Respir Infect; 9: 1928.

6- Park DR, Shetbin VL, and Goodman MS (2001). The etiology of communityacquired pneumonia at an Urban Public Hospital: Influence of Human Immunodeficiency Virus Infection and Initial Severity of Illness. $J$ of Infectious Diseases; 184: 268-77. 
7- Huchon G, Woodhead M, and Gialdroni-Grassi G (1998). Management of adult community-acquired lower respiratory tract infections. Eur Respir Rev, 8: 391-426.

8- Ishida T, Hashimoto T, Arita M, et al. Etiology of communityacquired pneumonia in hospitalized patients: a 3year prospective study in Japan. Chest 1998; 114:1588-1593.

9- Marrie TJ, Peeling RW, Fine MJ, et al. Ambulatory patients with communityacquired pneumonia: the frequency of atypical agents and clinical course. Am J Med 1996; 101:508-515.

10-Bochud PY, Moser F, Erard P, et al. Community-acquired pneumonia: a prospective outpatient study. Medicine (Baltimore) 2001; 80:75-87.

11-Wattanathum A, Chaoprasong C, Nunthapisud P, Chantaratchada S, Limpairojn N (2003). CommunityAcquired Pneumonia in Southeast Asia: The Microbial Differences Between Ambulatory and Hospitalized Patients. Chest 2003;123;1512-1519.

12- Bothe R, VanFurth R, and VanderBrock PT (1995). Etiology of communityacquired pneumonia: A prospective study among adults requiring admission to hospital. Thorax; 50: 543-547.

13-Sopena N, Sabria M, Pedro-Botet ML, Manterola JM, Matas L (1999). Prospective study of community- acquired pneumonia of Bacterial etiology in adults. Eur J Clin Microbiol Infect Dis; 18: 852-858.

14-Roux AD, Ewig S, Garcl'a E, Marcos MA, Mensa J, Lode H, Torres A (2006). Mixed community-acquired pneumonia in hospitalised patients. Eur Respir J; 27: 795-800.

15-Allmirall J, Morato I, Riera F, Verdaguer A, Priu R, Coll P, Vidal J, Murgi L, and Valls CF (1993). Incidence of community- acquired pneumonia and Chlamydia pneumoniae infection: A prospective multi center study. Eur Res Jour; 6: 14-18.

16- Macfarlane JT, Lim WS, Boswell M, Harrison TG, Rose D, Leinonen M and Saikku P (1997). Study of communityacquired pneumonia etiology in adults admitted to hospital: Implications for management guidelines. Thorax; 56 (4): 296-301.

17-Macfarlane J, Holmes W, Gard P, Macfarlane R, Roe D, Weston V, Leinonen M, Saikku $\mathrm{P}$ and Myint S (2001 ). Prospective study of the incidence, etiology and outcome of adult lower respiratory tract illness in the community. Thorax; 56 (2): 109-114.

18-El-Solh AA, Sikk P, Ramadan F, and Davies J (2001). Etiology of sever pneumonia in the very elderly. Am $J$ Resp Crit Care Med; 163: 645-651. 
19-Grayston JT (1992). Infections caused by Chlamydia pneumoniae strain TWAR. Clin Infect Dis; 15: 757-763.

20-Clyde WA (1993). Clinical overview of typical Mycoplasma pneumoniae infections. Clin Infec Dis; 17: 32-36.

21-Ruiz M, Ewig S, Torres A, Arancibia F, Marco F, Mensa J, Sanchez M, and Martinez JA (1999). Severe communityacquired pneumonia: Risk factors and follow-up epidemiology. Am J Res Crit Care Med; 160: 923-929.

22- Sarosi GA (1999). Atypical pneumonia, why this term may be better left unsaid. Postgraduate Med; 105 (4): 1-8.

23- Madhi SA, Klugman KP, Vaccine Trialist Group. A role for Streptococcus pneumoniae in virus-associated pneumonia.Nat Med 200 4; 10: 811813. 